\title{
Population Dynamics of Mackerel Scad (Decapterus macarellus) in the Banda Sea
}

\section{Frentje D. Silooy ${ }^{1 *}$, Agustinus Tupamahu ${ }^{1}$, O.T.S Ongkers ${ }^{1}$ and Haruna ${ }^{1}$}

\author{
${ }^{1}$ Fisheries and Marine Science Faculty of Pattimura University, Ambon ,Indonesia \\ *Corresponding author : frentje.silooy@fpik.unpatti.ac.id \\ ${ }^{1}$ Fisheries and Marine Science Faculty of Pattimura University, Ambon ,Indonesia \\ agus.tupamahu@fpik.unpatti.ac.id \\ ${ }^{1}$ Fisheries and Marine Science Faculty of Pattimura University, Ambon ,Indonesia \\ ongkers_tony@yahoo.co.id \\ ${ }^{1}$ Fisheries and Marine Science Faculty of Pattimura University, Ambon ,Indonesia \\ har flash@yahoo.co.id
}

\begin{abstract}
Mackerel scad is a one of small pelagic fish that has important economic value in the waters around Ambon Island. This study aims to determine population dynamics including the length distribution, growth, gonad maturity, mortality and the rate of exploitation of mackerel scad in the waters around Ambon Island. This research was conducted during the period of September 2016 to July 2017. Total fish samples analyzed were 2534 individuals. The total length (TL) offish caught during the eleven months of the research ranged from 9.0 $31.9 \mathrm{~cm}$ with an average length of fish caught of $20.11 \mathrm{~cm}$. Growth curve formed with the equation: $L_{t}=33.35$ [1-exp ${ }^{0.560}(t+0.2799]$. Gonad I maturity level was 8.13-10 16\%, TKG II (gonad II maturity level) was 46.49$49.11 \%$, TKG III (gonad III maturity level) was 16.54-18.93\%, TKG IV (gonad IV maturity level) 24.34 $26.02 \%$, and TKG V (gonad V maturity level) was $0.07-0.21 \%$, F value was $1.36 /$ year with the rate of exploitation $(E)$ of $0.53 /$ year, the total mortality rate $(Z)=2.58 /$ year and the natural mortality rate $(M)=$ 1.23/year.
\end{abstract}

Keywords-Decapterus macarellus, growth, gonad maturity level, mortality, exploitation rate, Banda Sea.

\section{INTRODUCTION}

Decapterus $s p$ is one of the potential fisheries resources and has important economic value in the Banda Sea. The fish is pelagic scall species are generally caught by purse seine. There are four species of Decapterus found in the Banda Sea, and one of them is mackerel scad (Decapterus macarellus). Mackerel scad belongs to one of the dominant species of pelagic fish caught throughout the year. It is an offshore fish because it has a vast distribution and can be caught at depths of 40-200 meters (Silooy et al., 2019; and Smith-Vaniz, W.F., 1999).

Atmadja et al., (2003) revealed that the catching of Decapterus using purse seine which was carried out without following the rules of fisheries resource management resulted in the fishing of small-sized young fish with immature gonad. In an effort to manage fisheries resources, especially mackerel scad, up-to-date information about these resources is needed. Information on the potential and level of utilization, population dynamics and biological aspects are needed so that the resources of small pelagic fish can be well managed and utilized sustainably.
This research was conducted to examine several aspects of population dynamics including size distribution and growth, gonad maturity level (TKG), mortality and exploitation rate of mackerel scad (D. macarellus) in the waters around Ambon Island. The results of this study are expected to be able to add and enrich existing information so that it can be used as a reference for consideration in the sustainable management of mackerel scad, especially in the waters around the island of Ambon and in Maluku waters in general.

\section{MATERIALS AND METHODS}

This research was carried out around the Banda Sea (Figure 1) for eleven (11) months (September 2016-July 2017) representing four fishing seasons, namely transition season 2, west season, transition seas on 1 and east season. $D$ macarellus fish samples were obtained from purse seine catches operating in the Banda Sea. Each sample was taken randomly at the fish-landing site and fishing port Ambon. The length of the entire fish samples was measured using a measuring board with a precision of 0.1 $\mathrm{cm}$. The type of measurement performed was the total body length, which is the length from the front end of the 
head or the tip of the mouth to the end of the tail. Body Weight was measured using a digital scale with an accuracy of 0.1 gram.

\section{Growth}

Estimation of growth parameters using the Von Bertalanffy growth formula (Sparre et al., 1999) was as follows:

$$
\mathrm{Lt}=\mathrm{L} \infty(1-\mathrm{e}-\mathrm{K}(\mathrm{t}-\mathrm{to}))
$$

Explanation:

$\mathrm{Lt} \quad=$ length of fish at the age of $\mathrm{t}(\mathrm{mm})$

Lo $\quad=$ Fish Asymptote Length (mm)

$\mathrm{K}=$ Growth rate coefficient

$\mathrm{t}_{0}=$ The theoretical age of the fish when the length is zero (years old)

$\mathrm{t} \quad=$ age (years old $)$

\section{Gonad Maturity Level}

Gonad Maturity Level was determined macroscopically and performed morphologically by observing the color, shape and size of the gonad according to Cassie in Effendie (1997).

\section{Mortality}

Natural mortality was estimated by using Pauly's empirical formula (1984) as follows:

$\log (\mathrm{M})=-0.0066-0.279 \log (\mathrm{L} \infty)+0.6543 \log (\mathrm{K})+$ $0.4634 \log (\mathrm{T})$
Explanation:

$\begin{array}{ll}\mathrm{L} \infty & =\text { Fish asymptote length }(\mathrm{mm}) \\ \mathrm{k} & =\text { Growth Rate Coefficient } \\ \mathrm{T} & =\text { Average surface water temperature (0C) }\end{array}$

Total mortality was assumed using the formula proposed by Beverton and Holt (1956) in Sparre et al., (1999), namely:

$$
\mathrm{Z}=\mathrm{KL} \infty-L L-L^{\prime}
$$

Explanation:

$$
\begin{array}{ll}
\mathrm{Z} & =\text { Total mortality rate (years) } \\
\mathrm{K} & =\text { Growth rate coefficient } \\
\mathrm{L} \infty & =\text { Fish asymptote length }(\mathrm{mm}) \\
\mathrm{L} & =\text { Average length of fish caught intact }(\mathrm{mm}) \\
\mathrm{L}^{\prime} & = \\
& \text { The smallest size limit of length class of fish } \\
& \quad \text { caught intact }
\end{array}
$$

Fishing mortality was predicted using the following equation:

$$
\mathrm{Z}=\mathrm{F}+\mathrm{M}
$$

So that:

$$
\mathrm{F}=\mathrm{Z}-\mathrm{M}
$$

The exploitation rate (E) was determined by comparing the fishing mortality rate $(\mathrm{F})$ with the total mortality rate (Z) (Pauly, 1984):

$$
\begin{array}{ll} 
& \mathrm{E}=\mathrm{F} /(\mathrm{F}+\mathrm{M}) \\
\text { If: } & \mathrm{E}>0,5: \text { Over Fishing }
\end{array}
$$

$\mathrm{E}=0,5:$ Maximum Sustainable Yield

$\mathrm{E}<0,5:$ Under Fishing

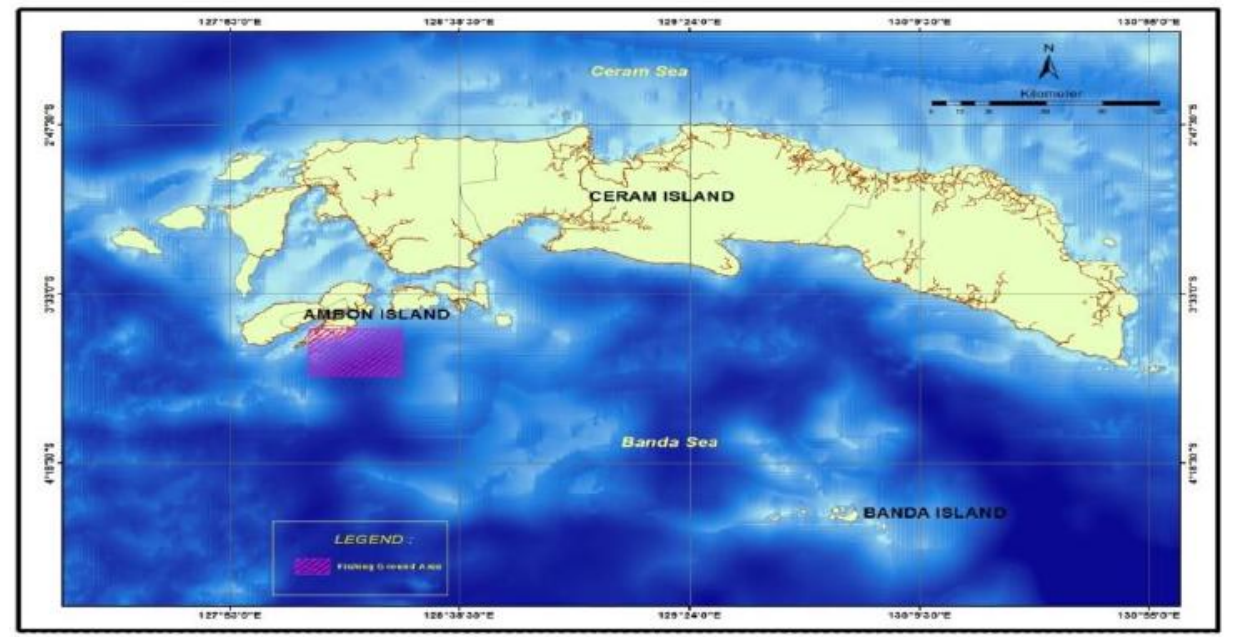

Fig. 1. Map of Mackerel scad (Decapterus macarellus) fishing operations in the Banda Sea

\section{RESULTS AND DISCUSSION}

\subsection{Distribution of the Length of the Fish}

This research was conducted during the period of September 2016 to July 2017. The total sample of fish analyzed was 2534 individuals (Table 1). The total length (TL) of fish caught during eleven (11) months of the study ranged from $9.0 \mathrm{~cm}$ to $31.9 \mathrm{~cm}$ with an average length of $20.11 \mathrm{~cm}$. Each month, the size of the fish caught varied. This was presumably because the mackerel scad population around the waters of the island of Ambon consists of several groups. This can be seen by the 
shifting of the length of the fish throughout the fishing period.

The length range of the mackerel scad obtained in this study was almost the same as the size range of fish caught in Banda Aceh waters ranging from $16 \mathrm{~cm}$ to $32 \mathrm{~cm}$, in the waters west of Sumatra ranging from $16-26 \mathrm{~cm}$, in the waters of the Tomini bay ranging from $16-27 \mathrm{~cm}$, in North Maluku waters ranging from $21-31.5 \mathrm{~cm}$ (Hariati
2004; Kusdi et al 2009; Widodo et al., 1999). According to Widodo (1988), Decapterus in the Java Sea mature at a size of $13.9 \mathrm{~cm}$ with a minimum decent size for fishing of $14.8 \mathrm{~cm}$. Prihatini (2006) stated that Decapterus with a size of $14.0 \mathrm{~cm}$ has been considered mature because it has reached TKG III. Based on the size of the fish caught in this study, it can be classified in adult fish group that is feasible for fishing.

Table 1. Distribution of the total length of mackerel scad in the waters around Ambon Island

\begin{tabular}{ccccccc}
\hline $\begin{array}{c}\text { Period } \\
(\text { month })\end{array}$ & $\begin{array}{c}\text { Quantity } \\
\text { (individual) }\end{array}$ & $\begin{array}{c}\text { Class } \\
\text { Interval } \\
(\mathbf{c m})\end{array}$ & $\begin{array}{c}\text { Mid } \\
\text { Length } \\
(\mathbf{c m})\end{array}$ & $\begin{array}{c}\text { Minimum } \\
(\mathbf{c m})\end{array}$ & $\begin{array}{c}\text { Maximum } \\
(\mathbf{c m})\end{array}$ & $\begin{array}{c}\text { Mode } \\
(\mathbf{c m})\end{array}$ \\
\hline Sep-16 & 354 & $23.0-29.5$ & 26.25 & 23.0 & 29.4 & 27.5 \\
Oct-16 & 339 & $18.0-21.9$ & 19.95 & 18.0 & 21.9 & 20.5 \\
Nov-16 & 410 & $9.0-31.9$ & 20.45 & 9.0 & 31.8 & 16.5 \\
Dec-2016 & 215 & $12.0-21.9$ & 16.95 & 12.1 & 23.9 & 18.5 \\
Jan-17 & 205 & $16.0-26.9$ & 21.45 & 16.0 & 26.9 & 20.5 \\
Feb-17 & 231 & $12.0-28.9$ & 20.45 & 12.0 & 28.7 & 20.4 \\
Mar-17 & 119 & $16.0-25.9$ & 20.95 & 16.2 & 25.8 & 20.5 \\
Apr-17 & 112 & $15.0-25.9$ & 20.45 & 15.1 & 25.9 & 23.4 \\
May-17 & 327 & $12.0-30.9$ & 21.45 & 12.2 & 30.8 & 18.3 \\
June-17 & 120 & $14.0-29.9$ & 21.95 & 14.2 & 29.9 & 20.4 \\
July-17 & 102 & $17.0-31.9$ & 31.9 & 17.1 & 31.8 & 24.5 \\
\hline Total/average & $\mathbf{2 5 3 4}$ & & $\mathbf{2 0 . 1 1}$ & $\mathbf{1 4 . 9 9}$ & $\mathbf{2 7 . 8 9}$ & \\
\hline
\end{tabular}

\subsection{Growth}

Based on the growth parameter formulas by Von Bertalanffy which was allegedly using the ELEFAN-I method, the growth rate coefficient $(\mathrm{K})$ value of the fish in the waters around Ambon Island tends to be slightly faster, namely 0.560 per year, with a longer asymptote length $(\mathrm{L} \infty)$ of $33.35 \mathrm{~cm}$, theoretical age of fish when the length is equal to zero (to) $=-0.2799$, and the Response Surface Rn (Goodness of fit index) $=0.227$, thus the growth curve obtained with an equation of $\mathrm{Lt}=33.35$ [1$\exp 0.56(t+0.27991]$. The estimated value of growth that expresses the relationship between growth patterns and the maximum age of the population is depicted in the form of a growth curve as shown in Figure 2.

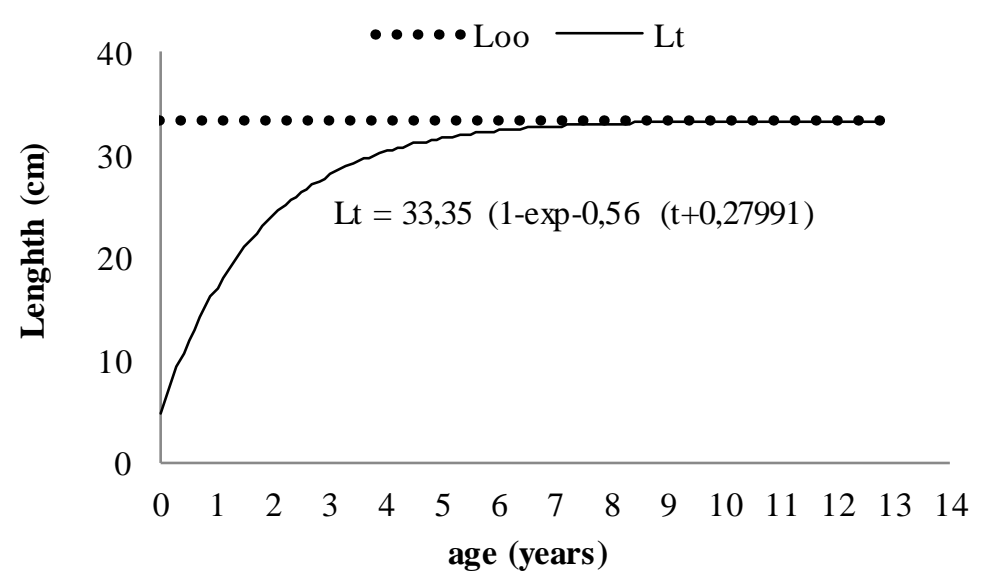

Fig 2. Estimated Growth Rate of Decapterus macarellus using von Bertalanffy formula in the Banda Sea 
The growth curve of this fish expressed the relationship between growth patterns and maximum age in the waters around Ambon Island. The growth rate of Decapterus population caught was relatively slightly faster $(K>0.5$ per year). This growth curve showed that mackerel reached a maximum length of $33.35 \mathrm{~cm}$ at 23.7 months old or 2.6 years old. At this age, there is no growth or addition of fish length or size. The results found that the growth was slightly faster than some previous studies, in which the maximum age of Decapterus in the Java Sea waters was around 5 years old (Widodo, 1998), and the maximum age of mackerel scad in North Maluku waters was around 4 years old (Iksan and Irham, 2009).

The growth parameters of D.macarellus species in several locations in Indonesia ranged from $25.6-33.57 \mathrm{~cm}$ for Lo parameter and ranged from 0.31 - 0.56 per year for $\mathrm{K}$ parameter. The difference in growth parameter values (Lo and $\mathrm{K}$ ) of the same species at different locations was greatly influenced by environmental factors, such as food availability, water temperature, dissolved oxygen, fish size, gonad maturity (Merta, 1992; Effendie, 1997; Widodo, 1988; Kaymaraman et al, 2014), the narrow range of sample sizes, the low length of asymptotes, and the limiting individual sampling results (Haruna et al., 2018).

\subsection{Gonad Maturity Level}

The results of observation on male and female gonad samples of Decapterus macarellus included the TKG I-V which were distributed in the range of class median of 17.5-31.5 cm. The gonad maturity levels consist of the young phase (TKG I) of $8.13-10.16 \%$, the initial maturity phase (TKG II) of $46.49-49.11 \%$, the mature phase (TKG III) of 16.54- 18.93\%, the spawning phase (TKG IV) of $24.34-26.02 \%$, and the saline phase (TKG V) of 0.07-0.21\%, can be seen in Figure 3.

Distribution of the total percentage of the number of individuals at each level of gonad maturity in each month for both male and female fish showed that the young and initial maturity phases were found almost throughout the year with the highest percentage respectively in October and December (around 93-100\%), the mature and spawning phases were found throughout the month except in October and December, where the highest average percentage was spread almost evenly in May to September in the range of 30-60\%, while the saline phase in this study was barely found, the percentage found in March was 1-3\%. The distribution of monthly gonadal development showed that the peak period when the mature gonads found was from May to September (Figure 4 and Figure 5).

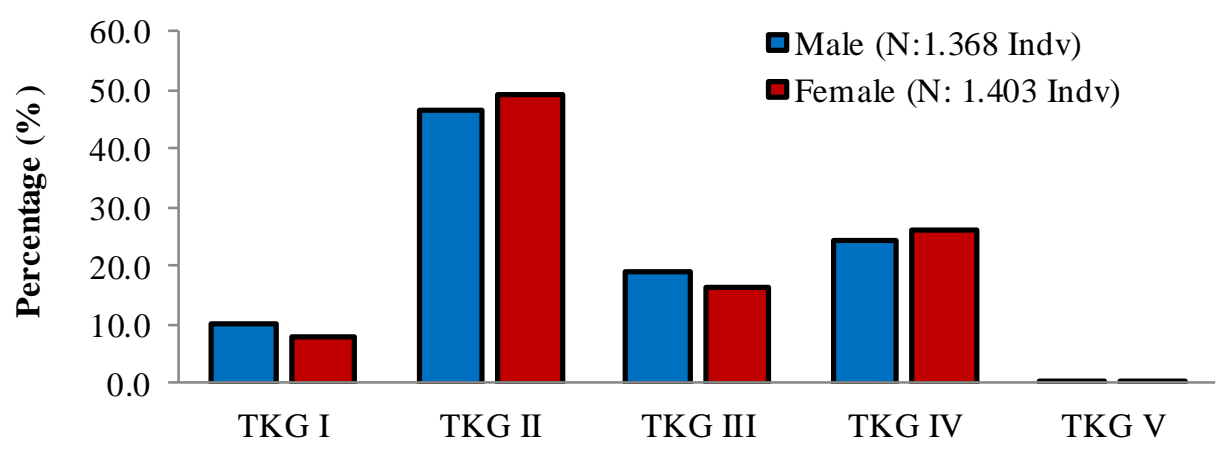

Fig 3. TKG percentage of Decapterus macarellus in the Banda Sea

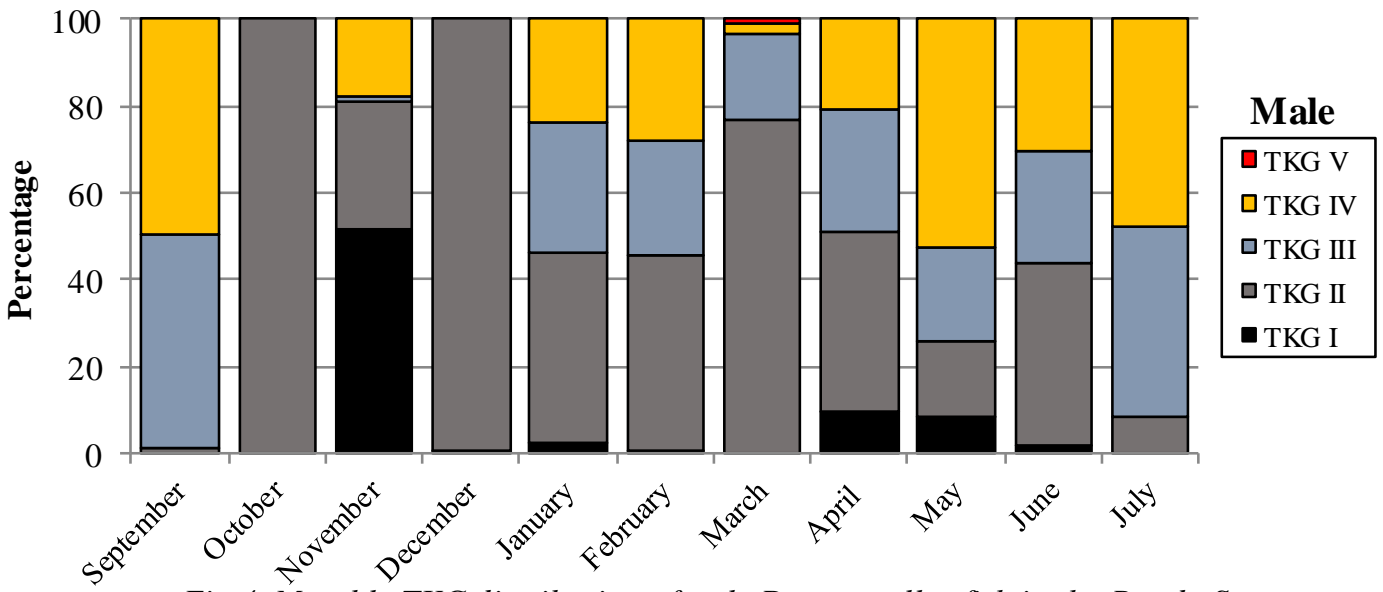

Fig 4. Monthly TKG distribution ofmale D. macarellus fish in the Banda Sea 


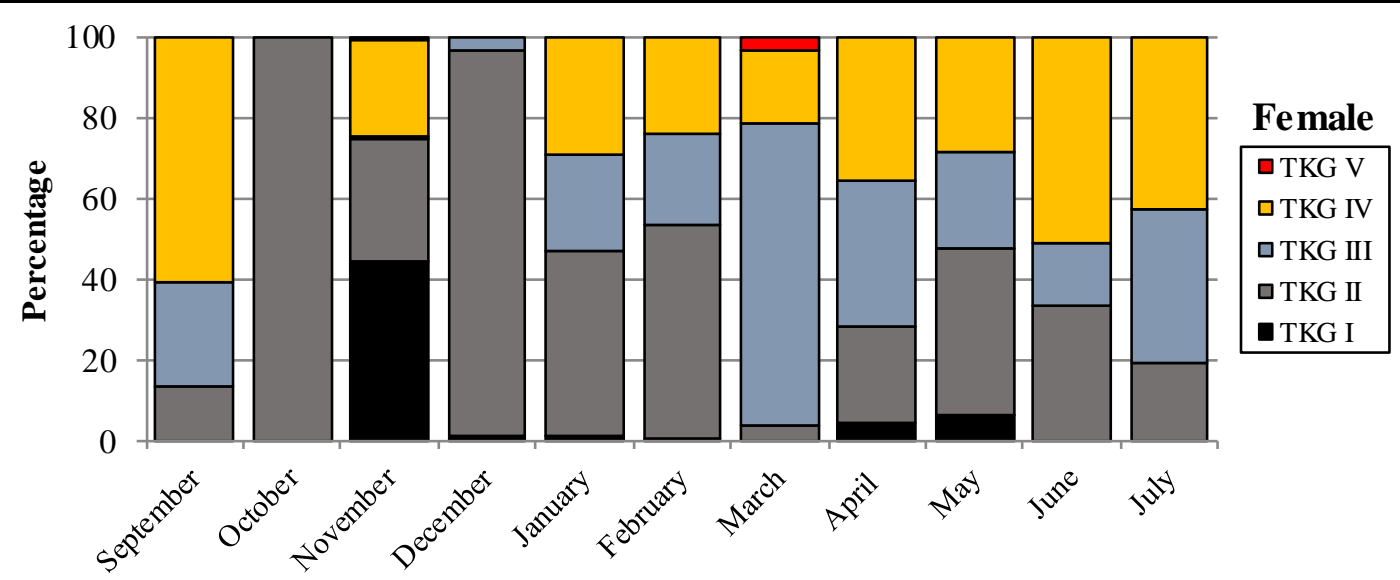

Fig 5. Monthly TKG distribution offemale D. macarellus fish in the Banda Sea

\subsection{Mortality and Exploitation Rate}

Estimation of mortality and exploitation rate based on the data on the composition of fish length size using the FISAT II program (Figure 6). The mortality of D. macarellus exploited was caused by a combination of natural mortality $(\mathrm{M})$ and mortality due to the fishing $(\mathrm{F})$. The waters around Ambon Island obtained an $\mathrm{F}$ value of $1.36 /$ year with an exploitation rate $(\mathrm{E})$ of $0.53 /$ year, total mortality rate $(\mathrm{Z})=2.58$ /year and a natural mortality rate $(\mathrm{M})=1.23 /$ year.

The assessment results indicate the fishing mortality $(\mathrm{F})$ is still greater than the natural mortality $(\mathrm{M})$, meaning that the mortality of $D$ macarellus fish in Ambon Island waters is caused by fishing factors. Judging from the rate of exploitation (E) in this study, namely 0.53/year, it is assumed that the pressure of fish exploitation is beyond the determined optimum sustainable value. The optimum exploitation rate occurs if there is a balance ratio between $\mathrm{M}$ and F, so it is assumed that the value of sustainable optimum exploitation (Eopt) is equivalent to $\mathrm{E}=0.50$ (Gulland, 1971).

This difference in the value of natural Mortality (M) has a relationship with the physical condition of the fish and the aquatic environment. According to Sparre and Venema (1999), the value of $M$ will depend on disease, stress, spawning, starvation, old age, and according to Beverton and Holt (1957), it is caused by predation. According to Kaymaraman et al., (2014) the difference is very determined by the use of estimation methods, observation locations and sensitivity to growth parameters, namely $\mathrm{K}$ and Lo.

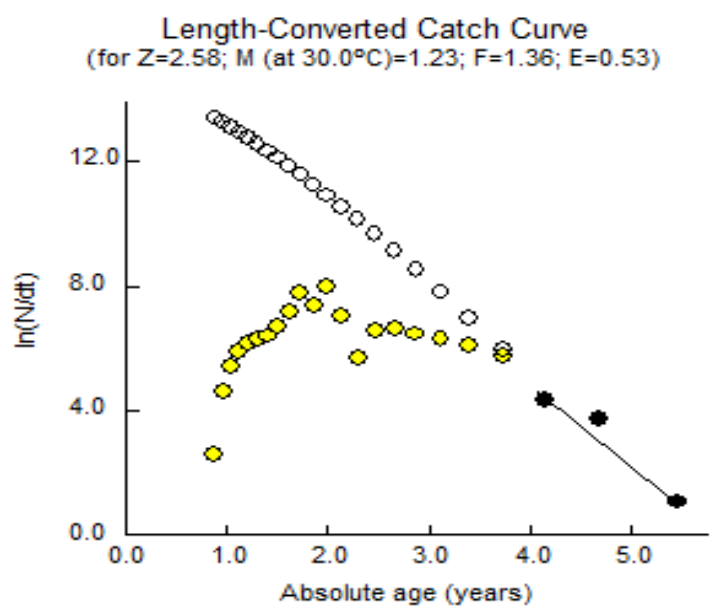

Fig 6. Mortality rate and exploitation rate of D. macarellus fish in the waters around Ambon Island

\section{CONCLUSION}

1. Total length (TL) of fish caught during eleven (11) months of research ranged from $9.0-31.9 \mathrm{~cm}$ with an average length of fish caught of $20.11 \mathrm{~cm}$.
2. Growth rate coefficient $(\mathrm{K})=0.560$ per year with a longer asymptote length $(\mathrm{L} \infty)$ of $33.35 \mathrm{~cm}$, the theoretical age of fish when the length is zero (to) $=$ -0.2799 , and Response Surface Rn (Goodness of fit 
index $=0.227$ thus obtained a growth curve with an equation of $\mathrm{Lt}=33.35$ [1-exp0.560 $(\mathrm{t}+0.2799]$.

3. Gonad maturity levels consist of the young phase (TKG I) of $8.13-10.16 \%$, the initial maturity phase (TKG II) of $46.49-49.11 \%$, the mature phase (TKG III) of $16.54-18.93 \%$, the spawning phase (TKG IV) of $24.34-26.02 \%$, and the saline phase (TKG V) of $0.07-0.21 \%$

4. Banda Sea obtained an F value of $1.36 /$ year with an exploitation rate $(\mathrm{E})$ of 0.53 year, total mortality rate $(\mathrm{Z})=2.58$ year and natural mortality rate $(\mathrm{M})$ $=1.23 /$ year.

\section{REFERENCES}

[1] Atmadja, S.B., D. Nugroho, Suwarso, T. Hariati, dan Mahisworo. 2003. Pengkajian Stok Ikan di WPP Laut Jawa. Prosiding Forum Pengkajian Stok Ikan Laut 2003. Pusat Riset Perikanan Tangkap. Badan Riset Kelautan dan Perikanan. Departemen Kelautan dan Perikanan (in Indonesia)

[2] Effendie, M. I. 1997. Fisheries Biology. Yayasan Pustaka Nusantara. Yogy akarta. $163 \mathrm{p}$

[3] Gulland, J,A, 1971. The Fish Resources of The Ocean Fishing News (Books) Ltd. Survey England

[4] Haruna, Mallawa A., Musbir, Zainuddin M., 2018 Population dynamic indicator of the yellowfin tuna Thunnus albacares and its stock condition in the Banda Sea, Indonesia. AACL Bioflux 11(4):1323-1333.

[5] Hariati, T., M. Taufik dan A. Zamroni. 2005. Beberapa aspek reproduksi ikan Layang (Decapterus russelli) dan ikan Banyar (Rastrelliger kanagurta) di perairan Selat Malaka Indonesia. JPPI, 11(2): 47-56. (in Indonesia)

[6] Iksan K.dan Irham. 2009. Pertumbuhan dan ikan Layang Biru (Decapterus macarellus) di Perairan Maluku Utara. Jurnal Iktiologi Indonesia 9(2): 163-174 (in Indonesia)

[7] Kaymaram F., Hosseini S. A., Darvishi M., 2014 Estimates of length-based population parameters of yellowfin tuna (Thunnus albacares) in the Oman Sea. Turkish Journal of Fisheries and Aquatic Sciences 14:101111.
[8] Kusdi H, Iksan dan Irham. 2009. Growth and Reproduction of Mackerel Scads, Decapterus macarellus (Cuvier, 1833) in North Moluccas Waters. Indonesia Journal Ichtiology. 9(2): 163-174,2009

[9] Prihartini, A., 2006. Analisis Tampilan Biologi Ikan Layang (Decapterus spp.) Hasil Tangkapan Purse Seine yang didaratkan Di PPN Pekalongan. Pogram Pasca Sarjana Universitas Diponegoro. Semarang. 89 hal (in Indonesia).

[10] Silooy.F. D, Soumokil, A. 2012. Analisa Struktur Populasi Ikan Momar (Decapterus macarellus) Di Sekitar Perairan Seri Pulau Ambon Bagian Selatan.Triton. Jurnal Manajemen Sumberday a Perairan (in Indonesia).

[11] Silooy F.D, Tupamahu A, Ongkers O.T.S and Matrutty D.D.P. 2019. Size Distribution and Growth Mackerel scad (Decapterus macarellus) in the Ambon Waters. International Journal of Environment, Agriculture and Biotechnology (IJEAB) Vol-4, Issue-2, M ar-Apr- 2019 http://dx.doi.org/10.22161/ijeab/4.2.34 ISSN: 24561878www.ijeab

[12] Sparre P dan Venema SC. 1999. Introduksi Pengkajian Stok Ikan Tropis Buku I- Manual (Edisi Terjemahan). Kerjasama Organisasi Pangan, PerserikataBangsa-Bangsa Dengan Pusat Penelitian dan Pengembangan Perikanan, Badan Penelitian dan Pengembangan Pertanian. Jakarta. 438 Hal (in Indonesia)

[13] Pauly, D., 1984. Fish Population Dynamics in Tropical Waters: A Manual For Use Programmable Calculators. Iclarms, Manila, 323pp

[14] Smith-Vaniz, W.F. 1999. Carangidae. In: Carpenter, K.E. \& Niem, V.H. (Eds.), FAO species identification guide for fishery purposes. The living marine resources of the western Central Pacific. Vol 4. Bony fishes part 2 (Mugilidae to Carangidae). FAO, Rome, Italy, pp. 2659-2756.

[15] Widodo, J. Dharmadi dan Suwarso., 1999. Distribution, abundance and population structure of Mackerel Scad, Decapterus macarellus, (CARANGIDAE) in the waters of North Sulawesi. Seminar on Management Plan for Tuna and Cakalang fisheries in Sulawesi and its surrounding waters. Pp. 9-12

[16] Widodo, J dan Suadi. 2006. Pengelolaan Sumber Daya Perikanan Laut. Gadjah Mada Universitas Press. Yogy akarta. 252 hal (in Indonesia) 